\title{
Pilinszky János a digitális térben
}

\author{
Sárközi Balázs
}

\section{János Pilinszky in the digital space \\ Abstract}

The aim of the study is to demonstrate the philological and textual opportunities of Pilinszky's poetry in the online field. The lifework of Pilinszky is not considered among the largest oeuvres. In spite of this, there are no critical editions of the Pilinszky-poems yet. Nevertheless, everything is ready for a full-scope critical edition; the philological research has revealed the whole life of János Pilinszky. Due to Pilinszky's diverse reception and the improvement of text encoding and data representation, literary studies nowadays have a great opportunity to execute this textual task in the world of the digital studies as well. This essay attempts to recommend a modern and forward-looking way to create the aforementioned Pilinszky-critical edition. So the essay tries to prove that there is a great potential in the literary database, which can be also useful in practical research, even considering the post-modern period. The main aim of the approach is to show that nowadays the academic studies and the world of computers are getting closer and closer to each other.

Keywords: digital philology; post-modern poetry; digital humanities; Pilinszky János; digital critical edition

Kulcsszavak: digitális filológia; posztmodern költészet; digitális humán tárgyak; Pilinszky János; digitális kritikai kiadás

Subject-Affiliation in New CEEOL: Language and Literature - Studies of Literature - Hungarian Literature

DOI: 10.36007/eruedu.2021.4.104-110

Annak ellenére, hogy Pilinszky János költői életműve nem tartozik a legnagyobbak közé, sőt kimondottan kisméretünek tekinthető, kritikai kiadása még nem készült el. A költői oeuvre viszonylagos kis mérete ellenére - az 1976-os, utolsó Kráter címü kötet, amely új versek mellett az összegyüjtött verseket tartalmazza, 220 költeményt sorakoztat fel (Tüskés 1996, 49), és a késöbbi gyüjteményes kötetek ezt a számot csupán körülbelül 40 költeménnyel és kevés számú zsengével egészítik ki - az életmű számos filológiai problémát felvet, amelyeket a filológiai kutatás már több esetben számba vett, ugyanakkor ezek megoldásában talán egy digitális filológiai adatbázis, egy digitális kritikai kiadás nyújthatna segítséget.

A kritikai kiadás hiánya mellett természetesen kiemelendő, hogy az irodalomtudományi kutatások eredményeképpen mára számos, a Pilinszky-életmű lírai szegmensét átfogó, valamint a levelezéseket, publicisztikai írásokat, naplóbejegyzéseket felsorakoztató kötet született, ${ }^{1}$ amelyek a teljesség igényével tárják fel az oeuvre

1 Hafner Zoltán munkái a Pilinszky-filológia szinte teljes egészét felölelik: Pilinszky János: Beszélgetések. (Szerk., szöveggond., jegyzetek, mutatók, utószó.) Századvég, Bp. 1994. - Jav., bőv. kiadás 
egészét, ugyanakkor a költői életmű filológiai nehézségeit talán nem oldják fel. A lírai alkotások esetén Pilinszky János publikáláshoz való hozzáállása - „Számomra ugyanis minden publikálás valószinütlennek tünt, s annak tünik máig is. Hogy a sorok, amiket fejemben hordtam, majd papírra vetettem, elidegenítve tölem, nyomtatott betűkkel megjelennek - hogyan is lehet ezt megemészteni? Hozzászoktam, hogy kézzel írok, és saját kézírásomnak még elhiszem, hogy létezik, hogy az enyém, köze van hozzám. De a nyomtatott betü? Persze, beletörödtem ebbe is. De ettöl kezdve az íás nem enyém, hanem másoké - $s$ így büntetés és ajándék egyszerre." (Rónay Lászlónak adott interjú. Idézi Tüskés 1986, 67-68) - a rendkivül sok címváltoztatás, a számos variációt, különbözőséget mutató ajánlások, valamint a versek számos szövegszerű változtatása (Tüskés 1996) mint filológiai problémák természetesen kevéssé megmutathatók, így pedig nehézkesen vizsgálhatók csupán gyüjteményes kötetek segítségével, kritikai kiadás nélkül.

Pilinszky János lírai életművének legteljesebb gyüjteményét a Domokos Mátyás és Hafner Zoltán szerkesztésében megjelent Pilinszky János összes versei című kötet adja (Id. 1. lábjegyzet), amely a korábbi, Jelenits István nevéhez füződő gyüjtéshez képest versekkel, a kéziratban maradt lírai darabok megjelentetésével, valamint töredékek kiadásával is bővült. A digitális térben a lírai életmü tekintetében mind a Petöfi Irodalmi Múzeum, mind pedig a Magyar Elektronikus Könyvtár felületein elérhetök gyüjteményes kötetek, azonban a MEK adatbázisában Pilinszky János összegyüjtött versei címmel az ugyanezen címmel Domokos Mátyás és Hafner Zoltán gondozásában a Századvégnél megjelent 1992-es gyüjtemény található meg, amely mind filológiai apparátusát, mind pedig a megjelentetett alkotások mennyiségét tekintve egy kevésbé átfogó korpuszt jelent. (Mindemellett a kötet felületén semmilyen bibliográfiai adat nem található meg - a szerzőségi, megjelenési adatok egy másik, „címkés formátum” jelzésű url alatt érhetőek el.) ${ }^{2}$

A PIM felületén elérhető Pilinszky János összes versei ${ }^{3}$ az azonos című Domokos Mátyás és Hafner Zoltán kiadásában megjelent kiadvány digitalizált változatát jelenti, vagyis tartalmazza a kötetböl kimaradt verseket, a meséket, a zsengéket, a hátrahagyott verseket és a töredékeket is, ilyeténképpen a lírai korpusz fellelhető legteljesebb gyüjteményének digitális változatát adja, ugyanakkor jellegéből és céljaiból adódóan a kutatás számára nem biztosít olyan filológiai adatokat és szö-

a Digitális Akadémia számára: 2003. Simone Weil: Kegyelem és nehézkedés. Pilinszky János forditásai. (Szerk., szöveggond., jegyzetek, utószó - Bende Józseffel közösen.) Vigilia, Bp. 1994. Pilinszky János: Naplók, töredékek. (Szerk., szöveggond., jegyzetek, mutatók, utószó.) Századvég, Bp. 1995. - Jav., böv. kiadása a Digitális Akadémia számára: 2002. Pilinszky fényképei. (Szerk., jegyzetek, utószó.) Pesti Szalon, Bp. 1995. Pilinszky János összes versei. (Szerk., szöveggond., utószó.) Osiris, Bp. 1996. - További jav., bőv. kiadások: 1998, 2001, 2002, 2003. Pilinszky János: Széppróza. (Szerk., szöveggond., jegyzetek, mutatók, utószó.) Osiris, Bp. 1996. ᄀ- 2. kiadás: 1998.; 3. jav. kiadás: 2004. Pilinszky János: Versfüzet, 1948. (Fakszimile; utószó.) Kortárs, Bp. 1996. Pilinszky János összegyüjtött levelei. (Szerk., szöveggond., jegyzetek, mutatók, utószó.) Osiris, Bp. 1997. Pilinszky Rómában. (Szerk., szöveggond., jegyzetek, utószó.) Kortárs, Bp. 1997. Pilinszky. - CD-ROM, Audio CD, Képeskönyv. Osiris, Bp. 1997. Pilinszky János: Publicisztikai írások. (Szerk., szöveggond., jegyzetek, mutatók, utószó.) Osiris, Bp. 1999. - A Tanulmányok, esszék, cikkek (1993) második, javitott, bővített, jegyzetelt kiadása. Levelek Pilinszkynek. (Vál., szerk., szöveggond., utószó, jegyzetek, mutatók.) Új Forrás, Tatabánya, 2012 
vegváltozatokat, amelyek tovább segítenék a Pilinszky-értelmezést. Mindazonáltal mindenképpen megjegyezendő, hogy a kritikai kiadás elkészítése nem formálná át, nem változtatná meg a Pilinszky-képet, ugyanakkor jelentős alkotáslélektani problémákat volna képes megvilágítani (Tüskés 1996, 49), valamint egyéb, kifejezetten nyelvi-poétikai és irodalomértelmezési kérdésekben lenne elengedhetetlen forrás (pl. a paratextuális elemek vizsgálatának lehetővé tételével, az ajánlások sokszínüségének, Pilinszky tudatos ajánlásírásának fényében, a címek és azok változásának tekintetében, vagy akár a csak részben politikai/ideológiai nyomásra történő szövegváltoztatások terén) és amennyiben digitálisan készülne el további, és talán az analóg térben kivitelezhetetlen filológiai-textológiai analízisek elvégzésének lehetőségét is megteremtené, akár szóstatisztikai vizsgálatok, adatvizualizációs technológiák tekintetében. Továbbá talán segítséget nyújtana az olyasfajta problémák feloldásában is mint a „Bajvivás volt itt...” kezdetű töredék kérdése, amely Ady Endre Minden titkok versei címü ciklusának egyik töredékeként is ismeretes, de Pilinszky János összes verseinek töredékei közé is bekerült 1961-es dátummal $(H$. Nagy 2001, 106-108). Egyébként a verstöredék mindkét változatban fellelhető a digitális térben is, a MEK felületén Ady Bajvivás volt itt kezdetű ciklusának nyitó darabjaként, ${ }^{4}$ míg a PIM felületén Pilinszky összes versei között, a Töredékek fejezet negyedik darabjaként. ${ }^{5}$

Természetesen mindkét gyüjteményes kötet digitális változata a nagyközönség számára, és nem az irodalomtudományi kutatás eszközeként készült, ilyeténképpen sem a teljesség, sem a kutatást segítő jelleg, sem pedig a felületkezelhetőség kutatást segítő jellemzői nem várhatók el velük kapcsolatban. Az utóbbiról az interface tekintetében - és természetesen a nagyobb méretű korpusz okán is - kijelenthető, hogy a PIM Pilinszky Jánoshoz tartozó adatbázisa egy bővebb és kereshető adatbázist jelent. A lírai alkotások vizsgálatát tekintve a digitalizált gyüjteményes kötet erényeként említhető, hogy a verses kötetek külön-külön, felugró lapban elérhetőek - nem darabokban, versenként - , valamint minden alkotás esetén feltüntetésre került az első megjelenés helye és ideje is, amely nem csupán a nagyközönség számára nyújt információkat. Ezek a bibliográfiai adatok azonban nem kereshetők, csupán egyenként fellelhetők, valamint a gyüjtemény url-jén ${ }^{6}$ sem található semmilyen keresési opció, rendezési lehetőség; erre csupán a PIM és a Digitális Irodalmi Akadémia Pilinszky János tematikus oldalán van lehetőség, ${ }^{7}$ ahol nem minden esetben egyértelmü, hogy az egyes keresési opciók esetén mi az az adatbázis, amely a keresés alapjául szolgál. A keresés a müvekben opció választása esetén ${ }^{8}$ hat szürö állítható be, amely a paratextuális elemekben való kereséstől a megjelenési adatokig megengedi a keresést, ugyanakkor a „művekben” szó úgy tetszik, hogy minden a költővel kapcsolatos írást magába foglal. A „trapéz” szóra való keresés esetén például elsődlegesen 21 találat jelenik meg, amelyek közül az első

\footnotetext{
4 https://mek.oszk.hu/00500/00588/html/vers0501.htm

5 https://konyvtar.dia.hu/html/muvek/PILINSZKY/pilinszky00001/pilinszky00323/pilinszky00323. html

6 https://konyvtar.dia.hu/html/muvek/PILINSZKY/pilinszky00373_kv.html

7 https://pim.hu/hu/dia/dia-tagjai/pilinszky-janos\#digitalizalt-muvek

8 https://pim.hu/hu/dia/dia-tagjai/pilinszky-janos\#kereses-a-muvekben
} 
Bözsöny Ferenc Költői hitvallás címü interjúja, ${ }^{9}$ emellett még hat interjú, két Nemes Nagy Ágnes-esszé, egy Németh László-levél, egy-egy Pilinszkytől származó levél és esszé, valamint (valószínüleg duplikátumként, az előző találatok forráshelyeként) a Beszélgetések, a Napló, töredékek, az Összes versei és a Publicisztikai írások címü kötet jelenik meg találatként, és csak ezek között a Trapéz és korlát című vers.

A Pilinszky-életmü érdekes szegmense lehet a hangzó vers, Pilinszky saját versmondásai. A költő köztudottan a hangzó vers híve volt, és számtalanszor mondott, szavalt saját versei mellett más remekműveket is. A filológiai kutatás felveti, hogy ebböl az orális költészethez közelítő attitüdböl kiindulva (Tüskés 1996, 51) - és talán hozzátéve Pilinszky írott szóhoz és a leírt, publikált szöveg költőtől való elválásához kapcsolódó gondolatait - talán feltételezhető, hogy a lírai életmű részét kell, hogy képezzék az ismert, fennmaradt Pilinszky-versmondások ${ }^{10}$ is (természetesen elsősorban a saját versek szavalatai). Ugyanakkor a hagyományos, ,,analóg” filológiai-textológiai kiadásmódszerek nehézkesen (esetleg CD-, DVD-melléklettel) lennének képesek kivitelezni a hangzó vers kritikai kiadásban való megjelentetését, amely számos más érv mellett tovább erősitheti az esetleges kritikai kiadás digitális textológiai módszerekkel és digitális térben való megjelenésének gondolatát. (Valamifajta hipertextualitást megvalósítva a fellelhető szövegváltozatok kiegészítéseként a fennmaradt szavalatok összekapcsolása a végleges szövegtestekkel esetleg gazdagithatja, kiegészitheti a Pilinszky-lírakorpusz teljességét.)

A Pilinszky János életművéhez kapcsolódó filológiai-textológiai kutatások több esetben nem értenek egyet abban, hogy mit szükséges a Pilinszky-oeuvre teljességének tekinteni. Kérdéses lehet a „csak a válogatott verseit megíró” (Tüskés 1996, 49) Pilinszkyvel kapcsolatban, aki azonban kiterjedt publicisztikai munkásságot is hátrahagyott, valamint esszéket irt, interjúkat adott, és a líra mellett más irodalmi münemek területén is próbákat tett, hogy melyek azok az elemek, amelyek még a múvészi, alkotói pálya részét képezik, és melyek azok, amelyek ezeken már kívül kerülhetnek. A polémia Pilinszky leveleinek kiadása után merült fel - „Zavarba ejtő mü, mondanám legszívesebben e több mint hétszáz oldalas kötetre, de mindjárt vissza kell kérdezzem magam, kinek a művéről beszélek, a filológus Hafner Zoltánéról, aki impozáns odaadással és szorgalommal rendezte sajtó alá, látta el jegyzetekkel ezt a csaknem nyolcszáz levelet (még ha a jegyzetek margóján tehető is néhány észrevétel), vagy a költőéről, aki semmiképp sem tekintette, nem is tekinthette leveleit az oeuvre részének." (Pályi 1998) - és amellett, hogy nehezen mérlegelhető kérdést feszeget, a Pilinszky-filológia, és valószínűsíthetően az egész Pilinszky János életművéhez kapcsolódó kutatás szempontjából fontos, hiszen a kérdés eldöntése nélkül is egyértelmünek tetszik, hogy mind a levelek, mind pedig minden más müfajú Pilinszky-szövegadalékokkal, alkotáslélektani, ars poeticai, alkotásfilozófiai háttérinformációkkal - még ha sok esetben a lírai szö-

9 https://opac.dia.hu/record/-/record/display/manifestation/Pilinszky_Janos-Beszelgetesek-pilinszky00990b/1cfe22ad-4f84-4f29-946e-e2197c3aeb9e/solr/0/24/0/21/authorOrder/ASC

10 Ilyen szövegváltozatoknak tekinthetö Pilinszky-szavalatok több helyütt megtalálhatóak a digitális térben. A talán a legkultikusabbnak tekinthetö Apokrif elmondott változata, az elmondás módja talán nem csupán egy Apokrif-szövegváltozatként vizsgálható, hanem egyéb prozódiai, nyelvi-poétikai és más értelmezi szempontokkal képes kiegésziteni, gazdagitani az irodalomtudomány Apokrif-értelmezését. https://www.youtube.com/watch?v=NV_kkX-ZvmA\&t=29s 
vegekkel ellentmondó gondolatokkal is - szolgálhat az irodalomértelmezés és a Pilinszky-kutatás számára. A Pilinszky-filológia kiemelkedő eredménye, hogy ezek a különböző müfajú szövegek teljességükben a kutatás rendelkezésére állnak, és egy közösen kereshetö, közös platformú adatbázisba rendezésük esetén számos lehetőséget nyújtanának akár a digitális kritikai kiadás megvalósulásának segítésére, akár újabb, digitális textológiai kutatások elvégzésére.

A digitális filológia ugyan egyértelműen kijelenti, hogy a számítógépes szövegolvasás, a digital humanities és a hálózati kultúra alapjaiban változtatta meg azt, hogy mit értünk szöveg alatt (Labádi 2013), azonban számos esetben az is világossá vált, hogy egyes filológiai-textológiai kihívások a számítógépes technológia (optimális) alkalmazása nélkül nem kielégítően megoldhatóak (Palkó 2016). A Pilinszky János életművéhez kapcsolódó filológiai kérdések, a korpusz mérete, amely a lírát tekintve nem túl nagy, de számos szövegváltozatot felmutató, az egész oeuvre figyelembe vételével azonban akár rendkívül kiterjedtnek is gondolható, valamint az a tény, hogy a filológiai apparátus és a szövegváltozatok szinte teljes egészében a kutatás rendelkezésére állnak, több esetben analóg módon kiadásra is kerültek, lehetővé és talán szükségessé teszi nem csupán egy kritikai kiadás megszületését, hanem a kritikai kiadás digitális filológiai módszerekkel történő digitális elkészitését is. A szemantikus web technológiájának alkalmazásával, platformfüggetlen és nyilt forráskódú eszközök felhasználásával, a digitális aggregáció segítségével (Palkó 2016) ${ }^{11}$ egy projekt keretében elképzelhető egy olyan Pilinszky-kritikai kiadás és Pilinszky-adatbázis, amely feloldja a szövegváltozatok és ajánlások kavalkádjának problémáját, hozzáférhetővé és korszerü digitális módszerekkel kutathatóvá teszi a filológiai kutatás által már elért eredményeket, valamint az eddig problémát jelentő orális költészetre, valamint az oeuvre teljességének kérdésére is megoldást képes nyújtani.

Mindazonáltal mindenképpen fontos lenne, hogy a Pilinszky-életmü digitális kritikai megjelenése a digitális filológia tudományterületének korszerü elvei alapján, a szövegkódolás legújabb eredményeinek figyelembevételével, az adatreprezentáció körvonalazódó kritériumaihoz igazodva történjék meg. A digitális szövegkiadásnak hazai viszonylatban is több évtizedes múltja van, amelyben sokáig, és föként a 2000-es évek első évtizede előtti periódusban a HTML-alapú kiadások és a fájlközpontú szemlélet uralkodtak, amely Pilinszky digitális térben való megjelenésének tekintetében is megfigyelhetö, hiszen az említett felületeken egy szövegegység egy fájlként reprezentálódik és csak ritkán található reflexió a szövegekkel kapcsolatban (Maróthy 2020, 9). (A legjobb esetben a szövegforrásról, megjelenési adatokról fellelhető közlés, de nem a szövegkódolásban, hanem az index oldalon.) A digitális filológiai praxis folyamatában megfigyelhető tendencia, hogy a korai digitális szövegkiadások vizuális adatkódolását a tudományterület módszertanának és gyakorlatának bővülésével egyre inkább az adatszerű megjelenítés váltja fel (Maróthy 2020, 9), amely leginkább az XML- és TEI-kódolásra való áttérést jelenti, ugyanakkor egy újonnan készülő digitális kiadás esetén talán eme kódolási metódus használatának érvénye is megkérdőjeleződhet, hiszen úgy tetszik, hogy az ún. stand-off markup alapú szintaxis a következő lépcső a digitális szövegmegjelenítésben. A szövegen kívüli markup lényege az, hogy külön rétegekként ilyen módon külön fájlokként

11 A korszerü, 21. századi digitális adatbázis kritériumaiként. 
kezeli a szöveget, és az ezekhez tartozó bárminemű szövegkritikai, filológiai, akár értelmezési állitásokat, vagyis kereshetővé, értelmezhetővé válik használata által a szöveggel kapcsolatos minden állitás, lehetővé válik ezek összevetése, új állítások megfogalmazása (Maróthy 2020, 9).

Pilinszky esetén az ilyesfajta, korszerünek tekinthető kódolás talán elengedhetetlennek tünik, hiszen a költői életmű kisméretü, ugyanakkor mind filológiai szempontból, mind pedig értelmezését tekintve masszív háttérrel bír, a kritikai kiadás teljességét ezen háttérszövegek elérhetősége és kutathatósága adná. Ugyanakkor minél összetettebb egy digitális szövegkiadás, minél kiterjedtebb adatbázissal és minél összetettebb kódolási rendszerrel bír, annál inkább kitett az elavulás és az elavulás okozta adatvesztés veszélyének (Golden 2020, 46), amihez mindenképpen hozzá kell tenni, hogy egy multidiszciplináris keretben kidolgozott, valóban korszerüen és jól használható digitális szövegkiadás rendkivüli finanszírozási hátteret is igényel, ami két olyan területét mutatja a digital humanities mai kérdéseinek, amelyek a Pilinszky-kritikai kiadás megvalósulását és megvalósulásának módszereit is komolyan veszélyeztethetik.

Fontos megjegyezni, hogy a szövegkódolás és adatbázis-építés trendjei mellett a digitális filológiának - így az esetleges Pilinszky-digitális kiadásnak is - egyéb, és a technikai megoldásoktól eltérő, inkább az „analóg-digitális” szembenállás szférájába mutató kérdéseknek is meg kell felelnie. Elengedhetetlennek tetszik, hogy a létrejövő adatbázis eléggé fókuszált legyen - esetünkben mindenekelött az életmü lírai elemeire és az azokhoz szorosan kapcsolódó adatokra koncentrálódjon - és emellett hozzáférhető, ellenőrizhető, minőségileg biztosított legyen - ehhez szinte teljességében rendelkezésre állnak a hagyományos filológiai eredmények - valamint nyilt forráskódú, korszerü adatkódolással müködő szoftvert alkalmazzon (Almási 2020, 26-27). Mindemellett mindenképpen világossá kell tenni, hogy - miként a már elkészült analóg, kiadott Pilinszky-művek, levelek, cikkek esetén is - a digitálisan közzétett szövegek, szövegváltozatok nem autonóm létezőként értelmezendőek, hanem a létrehozó elemző és a kódolási algoritmus által megalkotott absztrakciók (Almási 2020, 19). Vagyis óriási léptékű kontextualizációt tesznek lehetővé, amely a kutatás számára új, számítógéphasználat nélkül óriási munkát igénylő tendenciák, jelentéshalmazok elemzésére nyújt lehetőséget, ugyanakkor adatgyűjtési módszerként szükséges értelmezni őket, amelyeket minden esetben szövegkritikával kell illetni, valamint értelmezni és interpretálni szükséges (Labádi 2018, 19; Golden 2020, 37).

Valószínüsíthető azonban, hogy az irodalomtudomány felöl érkező hagyományos kritika, amely talán a „szöveg mágiája elvész” (Almási 2020,17) sorral foglalható össze a legjobban, Pilinszky esetében már érvényét kell, hogy veszitse. A digitális adatbázis elkészülte, a szavak feldarabolása, a feltételezett jelentések fázissal bíró és fázis nélküli adatokká mediálása, a számítógépes irodalomtudomány mérhető, kísérleti tudományjellege, nem képes a recepciótörténet, értelmezés és interpretáció korábbi eredményeinek annulálására, nem változtatja meg a megértés hermeneutikai-ontológiai eseményjellegét, hanem épp ellenkezőleg, további kvantitatív elemzések elvégzését, így stilometriai, filológiai, szöveggenetikai és bármilyen értelmezési lehetőségek lehetőségét nyújthatja. A szisztematikus interpretációt a 
digitális jelölőnyelvek segítségével megalkotott adatbázisok teszik lehetővé, azonban az így azonosítható hozzáadott jelentések csupán a szöveg elemeinek új irányú analízisét, és ebből fakadóan más szempontú interpretációját generálhatják (Golden 2020, 36-37). Pilinszky digitális térben való megjelentetése kapcsán is lényeges, hogy ne a létrejött adatbázis, az elemzésre megalkotott szoftver jelentsen önértéket (Almási 2020, 24), hanem az a potenciál, amely egy ilyen adatbázisban és az adatbázisból kinyerhető adatokban rejlik.

Természetesen egy digitális kritikai kiadás szövegváltozatok tömkelegével szembesítené az olvasót és a kutatót egyaránt, azonban amennyiben a Pilinszky-lírakorpusz paratextuális elemeinek, a költői szövegváltozatoknak és a címváltoztatásoknak a kavalkádjában való eligazodást segítené, a szövegváltozatok fellelhetőségének és a kereshetőségnek a kérdését megoldaná, és a stand-off markup kódolással a kanonizált szövegváltozatokat egyéb adatokkal gazdagítaná, valószinüsithetően hasznositható tudományos eredményekkel egészítené ki a Pilinszky-olvasást, vagyis ténylegesen irodalomtudományos eszközként volna képes funkcionálni.

\section{Irodalom}

Almási Zsolt (2020): Számítógépes irodalomtudomány. Helikon 2020/1., 16-31.

Domokos Mátyás (2000): Egy kis Pilinszky-filológia. Online: https://www.holmi. org/2000/09/domokos-matyas-egy-kis-pilinszky-filologia.

Golden Dániel (2020): Számítógép, szöveg, tudomány. Helikon 2020/1., 32-51.

H. Nagy Péter (2001): A filológia kérdés(esség)e, Ady és/vagy Pilinszky. Iskolakultúra 2001/3., 106-108. Online: http://real.mtak.hu/61120/1/EPA00011_iskolakultura_2001_03_106-108.pdf (Letöltés: 2020.09.03.)

Labádi Gergely (2013): „Digitális filológia”. In: Bevezetés az irodalomtudományba. Szerk. Balázs Mihály - Bognár Péter - Fazekas Sándor - Gere Zsolt - Labádi Gergely - Ötvös Péter. Mentor(h)áló 2.0 Program. TÁMOP-4.1.2.B.2-13/1-2013-0008projekt. Online: http:// www.jgypk.hu/mentorhalo/tananyag/Bevezets_az_irodalomtudomnybaV2/ii34_a_digitlis_ szveg.html (Letöltés: 2020.09.06.)

Labádi Gergely (2018): Az olvasó gép: Berzsenyi Dániel versei távolról. Digitális Bölcsészet 2018/1., 17-34.

Maróthy Szilvia (2020): A vizuális és az adatközpontú szemlélet. Helikon 2020/1., 5-15.

Palkó Gábor (2016): Mit jelent a digitális filológia a szemantikus web korában: a DigiPhil projektröl. Magyar Tudomány 2016/November. Online: http://www.matud.iif.hu/2016/11/07. htm (Letöltés: 2020.09.06.)

Pályi András (1998): Pilinszky János összegyüjtött levelei. Jelenkor 1998/3.

Tüskés Tibor (1986), Pilinszky János. Budapest: Szépirodalmi.

Tüskés Tibor (1996): Adatok a Pilinszky-filológiához. Tiszatáj 1996/11., 49-54. Online: http://tiszataj.bibl.u-szeged.hu/16353/1/tiszataj_1996_011_049-054.pdf (Letöltés: 2020.09.03.) 